\title{
Why Women Own Less, And Why It Matters More in Rural China's Urban Transformation
}

\section{Sally Sargeson}

\section{(2) OpenEdition \\ 1 Journals}

\section{Electronic version}

URL: http://journals.openedition.org/chinaperspectives/6025

DOI: 10.4000/chinaperspectives.6025

ISSN: 1996-4617

\section{Publisher}

Centre d'étude français sur la Chine contemporaine

\section{Printed version}

Date of publication: 7 December 2012

Number of pages: $35-42$

ISSN: 2070-3449

\section{Electronic reference}

Sally Sargeson, « Why Women Own Less, And Why It Matters More in Rural China's Urban

Transformation », China Perspectives [Online], 2012/4 | 2012, Online since 01 December 2015, connection on 28 October 2019. URL : http://journals.openedition.org/chinaperspectives/6025 ; DOI : $10.4000 /$ chinaperspectives.6025 


\title{
Why Women Own Less, And Why
}

\section{It Matters More in Rural China's}

\section{Urban Transformation}

\author{
SALLY SARGESON
}

\begin{abstract}
As the amount of wealth in China's economy grows, so too does the size of the gender asset gap. Nowhere is this gap more extreme, or its consequences for women's future wealth, subjectivity, and agency more serious, than in peri-urban sites where the conversion of farmland for development has sent property values skyrocketing. This article explores how the gender asset gap is being reproduced in the course of rural China's urban transformation. It queries the plausibility of the most common explanations for this gap, and suggests that Charles Tilly's theory of categorical sources of "durable inequality" offers a useful corrective to those explanations. Drawing on data collected from interviewees and survey respondents in Zhejiang, Fujian, Hunan, and Yunnan provinces between 2004 and 2012 and from secondary sources, the paper illustrates how, when villagers are compensated for the expropriation of their land and demolition of their agricultural and business activities and housing, Village Committees, patrilineal households, and local government authorities utilise gender categories to resolve distributional problems and differentially compensate men. Women become less likely than men to be acknowledged as, and have the capacity to fully act as, the owners, managers, and users of the assets whose value increases as a result of urbanisation.
\end{abstract}

KEYWORDS: inequality, property, gender, women, land, wealth, urbanisation, expropriation, China.

$\mathrm{C}$ omparative research suggests that government interventions supporting women's rights can reduce gender inequalities in property distribution. (1) Similarly, ceteris paribus, markets are less gender discriminatory in distributing assets than kinship and marriage institutions. (2) In light of this research, the gender asset gap in contemporary China is puzzling. In the mid-twentieth century, China's new socialist government wiped the slate clean when it came to the unequal distribution of productive assets. Women were recruited as participants in, and explicitly nominated as equal beneficiaries of, the redistribution and subsequent socialisation of rural land and urban enterprises. Their equal rights to inheritance, individual and marital property, and collective and public goods were guaranteed in legislation and policies, publicised in mass media and cultural performances, and enforced by courts. Increased investments in education dramatically improved gender equality in schooling. Women achieved one of the highest rates of labour force participation in the world. Fertility reduction meant that, at least in many urban families, daughters became their parents' sole beneficiaries. And the post-Mao expansion of markets and privatisation of many state and collective enterprises and housing removed barriers to women's purchase of property.

Yet China's women own far less than men. Rural women own least of all. But even in urban areas, women own less housing, business, and financial wealth, and fewer cars and major durable goods. (3) Moreover, during the first decade of the twenty-first century, the period on which this paper focuses, the gender asset gap grew wider. Indeed, as the amount of wealth in the economy grows, so too does the size of that asset gap. Nowhere is this gap more apparent, or its consequences for women's future capacities more serious, than around the margins of expanding cities where the conversion of farmland for urban development has sent property values skyrocketing. Nevertheless, the growth of gender asset inequalities in urbanising areas has been largely overlooked in both policy and scholarly studies. A recent World Bank publication examining the consequences of urbanisation in China, for example, fails to notice whether urban expansion affects gender property distribution. ${ }^{(4)}$

This article explores how the gender asset gap is being reproduced in the course of rural China's urban transformation. It queries the plausibility of the most common explanations for this gap, and suggests that Charles Tilly's theory of categorical sources of "durable inequality" offers a useful corrective to those explanations. ${ }^{(5)}$ In contrast to the most common explanations, Tilly's theory would lead us to anticipate that gender inequalities will endure as long as gender is enforced organisationally, institutionally, and ideologically, as a set of binary categories between which transactions repeatedly benefit one category. While the paper points to the effects of ideology, it primarily

1. Ann Varley, "Gender and Property Formalization: Conventional and Alternative Approaches," World Development, Vol. 35, No. 10, 2007, pp. 1739-1735; Carmen Diana Deere and Cheryl Doss, "The Gender Asset Gap: What Do We know and Why Does It Matter?", Feminist Economics, Vol. 12, No. 1, 2006, pp. 1-50; Bina Agarwal, "Gender and Command over Property: A Critical Gap in Economic Analysis and Policy in South Asia," World Development, Vol. 22, No. 10, 1994, pp. 1455-78.

2. World Bank Development Report, Gender Equality and Development, World Bank, Washington, 2012, p. 151

3. See, for example, the gap between male and female responses in Li Liao, Nuonan Huang, and Rui Yao, "Family finances in urban China," Journal of Family Economics, Vol. 31, 2010, pp. $259-279$.

4. Shahid Yusuf and Tony Saich, China Urbanizes: Consequences, Strategies and Policies, Washington, World Bank, 2008; UN Human Development Report China 2007/8 Access for All: Basic Public Services for 1.3 billion people, Beijing, UNDP, 2008; Zhen Yan (ed.), Zhongguo nongcun funü zhuangkuang diaocha, Beijing, Shehui kexue wenxian chubanshe, 2008.

5. Charles Tilly, Durable Inequality, Berkeley (CA), University of California Press, 1998; Charles Tilly, "Changing Forms of Inequality," Sociological Theory, Vol. 21, No. 1, 2003, pp. 31-36. 
focuses on how organisations utilise gender categories to naturalise unequal asset distribution between men and women in urbanising areas of China.

The exploration is presented in five sections. The first section defines and explains why asset inequalities matter more in the context of urbanisation. Section two surveys evidence of the gender asset gap in rural areas. The third section examines three widely-accepted narratives explaining gender inequalities. Analysis of these narratives is relevant for two reasons: first, it helps elucidate reasons for contemporary asset distributions; second, matched against available empirical evidence, the analysis is a useful test of the explanatory power of the narratives themselves. It will be shown that although these explanations do yield important insights into sources of gender inequality, each also fails to account for the reproduction of the gender asset gap in the context of urbanisation. A case is then made that Tilly's theory provides a more robust account of why the asset gap persists. In the fourth section, I draw on data collected from a total of 280 interviewees and 1,050 survey respondents during field trips to peri-urban sites in Zhejiang, Fujian, Hunan, and Yunnan provinces between 2004 and $2012^{(6)}$ to illustrate how, when villagers are compensated for the expropriation of their land and demolition of their agricultural and business activities and housing, Village Committees, households, and local government authorities utilise gender categories to resolve distributional problems, and differentially compensate men. Women become less likely than men to be acknowledged as, and have the capacity to fully act as, the owners, managers, and users of the assets whose value increases as a result of urbanisation. Instead, women are reincorporated into the urban economy as workers in, domestic caretakers of, and dependents on assets owned by the state and male-headed businesses and households. The final section concludes that unless government intervenes to reduce the gender asset gap, gender inequalities will intensify in the course of rural China's urban transformation.

\section{Why the gender asset gap matters in urbanising China}

As most studies of gender inequalities in China's economy focus on labour markets and incomes, before surveying the asset gap it is worth clarifying the core concepts under discussion and explaining why the gender asset gap should matter to anyone trying to understand how women will fare in China's urban future. Assets include both tangible and intangible goods. Following conventional usage, institutions are conceived to include the whole panoply of laws, rules, policies, kinship structures, marital regimes, cultural values, and customary practices that normatively define conditions for people's interactions and behaviour with regard to assets.

Some scholars argue that, compared to income, during the course of industrialisation and urbanisation assets serve as a more holistic and reliable indicator of current and intergenerational trends in people's economic capacity, well-being, and social standing. Asset stocks, according to Deere, Alvarado, and Twyman, are more stable and of broader composition, and they provide a better buffer against market shocks. ${ }^{(7)}$ Consider, for example, the ways in which people might benefit from owning the two types of assets discussed below - land and housing. Land and housing provide shelter and security. They accommodate production for home consumption. In postsocialist countries such as China, the introduction of user-pays principles in the health and welfare sectors has increased the precautionary necessity to accumulate fungible assets such as housing. ${ }^{(8)}$ The creation of a real estate market and privatisation of much housing stock means that housing can earn rental income, be sold in cases of emergency, or gambled, gifted, or willed. Houses and land can appreciate in value over time, and in urban areas they can be used as collateral to secure loans for further investment. Moreover, the ownership of material goods such as land and housing generates social multiplier effects. By visibly coding owners' wealth and class positioning, they amplify their marital prospects, political 'voice,' and thus their business opportunities. ${ }^{(9)}$ In short, assets protect against present want, hedge against future risks, and produce more wealth. ${ }^{(10)}$

In capitalist economies, wealth skews income distribution, as the highest incomes derive not from salaries and wages, but from capital appreciation, share dividends, and rents. ${ }^{(11)}$ Since the 1990s, the key contributor to income inequality in China similarly changed from differentials in social and human capital to unequal wealth ownership in both rural and urban areas. ${ }^{12)}$ Wealth has grown at a much faster rate than income. Between 1995 and 2002, annual per capita net wealth in urban areas grew three times faster than income. Nationwide, per capita net wealth tripled between 2000 and 2011. ${ }^{(13)}$ As in other emerging markets, the ownership of tangible assets such as enterprises and housing became the prime means of accumulating wealth. ${ }^{(14)}$ In fact, housing represents the single largest component of household and individual wealth. ${ }^{(15)}$

The unprecedented pace and scale of urbanisation partly accounts for the dramatic increase of personal wealth in China. Urbanisation has become a key driver of China's economic growth, with almost 370 million people added to the urban population between 1990 and 2011. In all countries, the value of farmland increases when it is re-zoned for development and construction. In China, though, additional utility and hence exchange value comes from the administrative reclassification of rural areas as urban industrial or residential. National laws, banks' risk assessment procedures, and local practices prevent villagers in most areas from leasing collectivelyowned rural land for development and construction, using land and housing as mortgage collateral, and selling rural housing. Thus, much of this wealth

6. Methodology is explained in Sally Sargeson and Yu Song, "Land Expropriation and the Gender Politics of Citizenship in the Urban Frontier," The China Journal, Vol. 64, 2010, pp. 19-45; Sally Sargeson, "Women's Property, Women's Agency in China's 'New Enclosure Movement': Evidence from Zhejiang," Development and Change, Vol. 39, No. 4, 2008, pp. 641-665; Sally Sargeson, "Governing Women's Capabilities in China's Urban Expansion," International Feminist Journal of Politics, Vol. 9 , No. 2, 2007, pp. 154-175; Sally Sargeson, "Building for the Future Family," in Anne E. McLaren (ed.), Chinese Women - Working and Living, London, RoutledgeCurzon, 2004, pp. 149-168.

7. Carmen Diana Deere, Gina E. Alvarado, and Jenifer Twyman, "Gender Inequality in Asset Ownership in Latin America: Female Owners vs Household Heads," Development and Change, Vol. 43, No. 2, 2012, pp. 505-530.

8. Fungible assets can be converted to cash.

9. Nicholas Blomley, "Law, Property and the Geography of Violence:The Frontier, the Survey and the Grid," Annals of the Association of American Geographers, Vol. 93, No. 1, pp. 121-141.

10. Greg M. Olsen, Power and Inequality: A Comparative Introduction, Don Mills (Ontario), Oxford University Press Canada, 2011.

11. Joseph E. Stiglitz, The Price of Inequality, London, Allen Lane, 2012.

12. Yingying Zhou, Hua Han, and Stevan Harrell, "From Labor to Capital: Intra-Village Inequality in Rural China, 1988-2006," China Quarterly, Vol. 195, 2008, pp. 515-534.

13. Xin Meng, "Wealth Accumulation and Distribution in Urban China," Bonn, IZA (Institute for the Study of Labor), Discussion paper No. 2553, 2007, p. 8; Credit Suisse Research Institute, Global Wealth report 2011, https://infocus.credit-suisse.com/data/_product_documents/_shop/323525/ 2011_global_wealth_report.pdf (consulted on 13 July 2012).

14. Thomas A. Peltonen, Ricardo M. Sousa, and Isabel S. Vansteenkiste, "Wealth effects in emerging market economies," International Review of Economics and Finance, Vol. 24, 2012, pp. 155-166.

15. Shi Li and Renwei Zhao, "Changes in the Distribution of Wealth in China, 1995-2002," UNU-WIDER Research Paper No. 2007/3, 2007; A 2008 survey found that the mean value of rural households' agricultural assets was 1,845 yuan, and non-agricultural assets, including housing, were worth 70,683 yuan. See Klaus Deininger, Songqiang Jin and Fang Xia, "Moving off the farm: Land institutions to facilitate structural transformation and agricultural productivity growth in China," World Bank Policy Research Working Paper No. 5949, Washington, World Bank, 2012. 
remains "socialised." In contrast, in urban areas land leases and housing are fungible, in great demand, and privately owned by individuals. Thus, when villages are encompassed by spreading cities and towns and their land is zoned for urban development, the value of these assets increases, as does their owners' capacity to accumulate additional wealth.

A final point to emphasise is how the gender asset gap might affect other aspects of gender relations. ${ }^{(16)}$ Gender asset inequalities exacerbate gender inequalities in power, agency, and functioning. Without registered and acknowledged property rights, women have limited capacity to independently manage, use, capitalise on, and dispose of their home or land. Women's asset ownership improves their influence and well-being within households. Conversely, as feminist scholars have pointed out, women's bargaining position in the household and their ability to escape domestic violence is weaker if they have no property to fall back upon. (17) Even in community property regimes, in which property acquired during the marriage is jointly owned by the spouses, when women who are not registered as property owners divorce, they bear higher transaction and opportunity costs in attempting to defend their rights to marital assets. ${ }^{(18)}$ Mothers' ownership of incomegenerating assets improves the welfare of other household members, as it correlates with lower dependency ratios and higher expenditure on nutrition, education, and social insurance. Further, it leads to less gender discriminatory expectations and behaviours among the children from their households.

In short, the gender asset gap matters more as China urbanises. And it matters particularly to women. If we are to understand why it is that women are not sharing equally in the wealth created by rural China's urban transformation, we first need to make sense of how property institutions link gender and asset distributions across time, space, and rural /urban administrative boundaries.

\section{The gender asset gap in rural China}

Comparable evidence on the gender distribution of rural land and housing is limited. There is a high degree of inter-village variation in rules relating to collective land, a low rate of certification of rural land rights and house ownership, and no national gender-disaggregated data on rights to land and housing in either urban or rural China. With these caveats in mind, the following overview draws on published sources and my own fieldwork to provide descriptive statistics on the distribution of rights to administer, manage, and contract collective farmland and occupy village house sites, and house ownership.

Rural land ownership is vested in rural collective economic organisations. In most locations, the collective owner is represented by the Village Committee. Elsewhere, it might be the sub-village small group, Village Shareholding Corporation, or the lowest level of the state's bureaucratic hierarchy, the township. Here, for the sake of simplicity, I simply refer to "the village" as owner. Villages are entitled to administer, lease, contract use rights to, and manage income from land and other collectively-owned assets. Since 1979 , village ownership and administrative rights progressively have been separated from land management and contracted use rights. While there is considerable variation among the entities using rural land, village households comprise the majority of land contractors. In early rounds of contracting in the 1980s, villages allocated farmland based on the numbers of people per household. Every few years, they then adjusted land distribution to accommodate changes in household size resulting from births, deaths, marriages, and divisions. Over the past two decades, the legal right of villages to adjust land among households has been curtailed, while the duration of land contracts has lengthened and contractors' rights to use and profit from the land and exchange their contract rights have been strengthened. These changes were consolidated in the 1998 Land Management Law (hereafter, LML) and the 2002 Rural Land Contract Law (RLCL).

There is little direct evidence of gender disparities in the administration and management of collective assets. However, from studies of women's political participation in village government, we know that until 2009, women comprised around 16 percent of the membership of Village Committees and almost one quarter of the committees included no women. ${ }^{(19)}$ Less than 1 percent of Village Committees heads and only 3 percent of Communist Party members in rural areas were female. (20) Village representative assemblies and meetings typically were attended by household heads, more than 90 percent of whom were male. (21) Women consequently were underrepresented in the organisations and meetings that decided on collective investments, public infrastructure construction, applications for contract land and house sites, and the distribution of subsidies and dividends from land revenue. Song and I found that among 208 women living on the outskirts of Fuzhou and Changsha, less than 4 percent of women in the first site and 21 percent in the second had participated in a village assembly in the 12 months prior to expropriation of their villages' land, when critically important questions about compensation eligibility were being settled. (22) Following widespread criticism of women's under-representation in village government, in 2010 the Organic Law of Village Committees was amended to stipulate that each Village Committee must include a woman, and one third of village assembly representatives must be female. Yet although women's proportionate representation consequently increased, women have reported little improvement in their capacity to influence the rules regarding collective assets. As a Zhejiang interviewee reflected:

Women don't usually participate in any decision making. They (the cadres) make the decisions. So I can't tell if my "say" has changed because I don't have any "say." I know there are village rules, but I don't know where, I don't know when they were made, or if they've been revised. I haven't seen them. But actually, the village rules are even more important to us than the laws! (23)

16. World Bank Development Report, Gender Equality and Development, op. cit, p.151.

17. Carmen Diana Deere and Cheryl Doss, "The Gender Asset Gap: What Do We know and Why Does It Matter?", art. cit.

18. Chunyan Zheng, "Lun lihun anjian zhong nongcun funü quanyi de baohu" (Theorizing the protection of rural women's rights in divorce cases), Zhongwai qiyejia (Chinese and Foreign Entrepreneurs), No. 6, 2011, pp. 160-162.

19. Xiajuan Guo, Yongnian Zheng, and Yang Li, "Women's Participation in Village Autonomy in China: Evidence from Zhejiang," China Quarterly, No. 197, 2009, pp. 145-164; Juan Ding, "Zhongguo funü de zhengzhi canyu zhuangkuang" (The state of women's political participation in China), in Lin Tan (ed.), 1995-2005 nian: Zhongguo xingbie pingdeng yu funü fazhan baogao (1995-2005: report on gender equality and women's development in China), Beijing, Shehui kexue wenxian chubanshe, 2006, pp. 52-64.

20. Jude Howell, "Women's political participation in China: In whose interests elections?", Journal of Contemporary China, Vol. 15, No. 49, 2006, pp. 603-620; Xiaohong Liu and Zhiping Wu, "Funü zai cunweihui xuanju zhong de jingxuan celüe yanjiu" (Research on women's campaigning strategy when participating in village elections), Funü yanjiu luncong (Collection of women's studies), No. 1, 2008, pp. 15-20.

21. Zhen Yan (ed.), Zhongguo nongcun funü zhuangkuang diaocha (Survey on the situation of China's rural women), op. cit;; Yong Zhang, "Nongcun funü canyu cunweihui xuanju de xianzhuang jiqi yingxiang yinsu" (The current situation and factors influencing rural women's participation in village elections), Shehui (Society), No. 6, 2004, pp. 26-29.

22. Sally Sargeson and Yu Song, "Land Expropriation and the Gender Politics of Citizenship in the Urban Frontier," The China Journal, no. 64, July 2010.

23. Interview, Kaihua, April 2012. 
Clearer evidence is available on the gender gap in land contracting. In law, policy, and custom, land use rights are conceptualised as being contracted to households. (24) But within households, there are five significant disparities between the entitlements of male and female household members. First, when villages originally distributed contract land in the 1980s, although adult men and women usually were allotted equal portions, in many regions male children were granted double the portion allotted to girls. ${ }^{25}$

Second, although the names of all adult household members may be listed on land contracts, and although women perform a great deal of farm work, most land contracts only include men's names. Of 414 land contracts held by farming households in Zhejiang, Fujian, Hunan, and Yunnan, I found that less than 20 percent included women's names. (26) Where women's names did appear they were either listed jointly with other family members or there were no adult able-bodied males in the household. This was comparable to the finding of the 2011 Landesa survey, in which women were listed on only 17.1 percent of land contracts. (27) However, in Sichuan, Shaanxi, Gansu, Ningxia, and Jiangxi, none of the 281 villagers interviewed by Li Xiaoyun and his colleagues had included women's names on their contracts. ${ }^{28}$ According to a woman farmer in Yunnan, contracts automatically are registered in men's names: "It's the women who marry in, we're considered to be outsiders. Men are recognised as locals, the members of village households. So the village leaders always write the men's names. Usually they don't even ask us, just put everything under his name." (29)

Third, within households, the security and scope of men's and women's land contract rights differ. This gender gap is most apparent when villagers' marital status changes. When women marry non-local men or divorce local men, many risk being denied use of the households' contract land. When men's marital status alters, however, few face the same risk. ${ }^{(30)}$ A 2004 crossnational survey by the Women's Federation found that women made up 70 percent of landless villagers. The Third National Survey on the Status of Chinese Women in 2010 found that since 2000, the percentage of landless women had increased almost 12 points, to 21 percent. Among all landless villagers, 27.7 percent of women had lost their use rights as a direct result of marriage, divorce, re-marriage, or widowhood, but only 3.7 percent of men had become landless for these reasons. ${ }^{(31)}$ The expansion of markets and recent legislative changes have further undermined married women's security with regard to household contract land. Escalating rates of male out-migration and off-farm employment have led to a gendered division of household agricultural management and production. Male land contract signatories who work away often still decide on the use of and investments in plots tilled by their unwaged wives and mothers. ${ }^{(32)}$ The RLCL and 2007 Property Law enable land contract signatories to sell, lease, and transfer their use rights. Hence, unless local implementation regulations explicitly require spousal consent, most women have no legal grounds on which to prevent men's disposition of the contract land they farm. ${ }^{(33)}$

Fourth, compared to men, women profit less from the output and exchange of their households' contract land. (34) Many rural households have only one savings account, which is registered in the name of the household head. Income from agriculture and land rent is deposited into this single account. Women therefore rely upon the goodwill of their fathers, husbands, or sons to gain access to savings. Despite having farmed land contracted by her husband for more than two decades, one woman I interviewed in Yunnan commented, "I've never had my own money. Really, I'm not kidding you. Not one fen of my own." (35)

Finally, there are severe gender disparities in the distribution of rural housing. In villages that have space and planning approval for new housing, ir- respective of the number of sons in a family, each adult son may be allocated a house site. But it usually is only in households without able-bodied sons, that one - and only one - adult daughter may receive a site. More than 90 percent of rural households own housing, yet very little rural housing is registered in women's names. I calculated that less than 15 percent of rural women have title to the houses in which they lived. (36) Li Xiaoyun and his colleagues similarly concluded that there is "serious gender inequality in the use, construction, capital resources and distribution of houses." (37) In sum, the available evidence shows that there is a severe gender asset gap in rural areas. Why does this gap occur, and how might it be altered in the context of rural China's urban transformation?

\section{Narratives of gender inequality}

One of the most common explanations for gender inequality is that Confucian patriarchal traditions persist in rural areas. For example, Wang cites the tenacity of Confucian values as the reason why villagers idealise the patrilineal household as an indivisible property-owning, production, and consumption unit in which men's and women's interests are presumed to be homogenous, even though their power, resources, and workload are unequal. (38) Within the household, Chen argues, men's household headship and gender divisions of labour are legitimated every day in patriarchal maxims such as "husbands are superior, wives subordinate," "men manage outside, women manage inside," and - with regard to the

24. Ellen Judd, "No change for thirty years: The renewed question of women's land rights in rural China," Development and Change, Vol. 38, No. 4, 2007, pp. 689-710.

25. Junjie Chen and Gail Summerfield, "Gender and Rural Reforms in China: A Case Study of Population Control and Land Rights in Northern Liaoning," Feminist Economics, Vol. 13, No. 3-4, 2007, pp. $63-$ 92; Hainan gaige fazhan yanjiusuo (Hainan Research Center for Reform and Development), Zhongguo nongcun funü tudi quanli diaoyan baogao (Report on research into rural women's land rights in China), presented at international symposium on protection of rural women's land rights and new breakthroughs in rural reform, Haikou, 20-22 January 2003.

26. Sally Sargeson and Yu Song, "Land Expropriation and the Gender Politics of Citizenship in the Urban Frontier," art. cit:; Sally Sargeson, "Women's Property, Women's Agency in China's 'New Enclosure Movement,"' art. cit.

27. "Summary of 2011 17-province survey's findings," www.landesa.org/china-survey-6/ (consulted on 30 February 2012).

28. Xiaoyun Li et al., "Gender Inequality and Poverty in Asset Ownership," Chinese Sociology and Anthropology, Vol. 40, No. 4, 2008, pp. 49-63.

29. Interview, Yuxi, May 2008

30. Lirong He, "Chujia nü tudi quanyi baohu de kunjing yu chulu" (Difficulties and ways to protect outmarried women's land rights), Hebeifaxue (Hebei legal studies), No. 9, 2008, p. 129.

31. Quanguo Fulian (All-China Women Federation), "Di san ci Zhongguo funü shehui diwei diaocha zhuyao shuju baogao" (Report on the main results from the third survey on Chinese women's status), Funü yanjiu luncong (Collection of women's studies), Vol. 6, No. 108, 2011, p. 12.

32. Zheng Yan, Zhongguo nongcun funü zhuangkuang diaocha, op. cit;; Ping Xu, "Hunying liudong yu nongcun funü de tudi shiyong quanyi," (Marriage mobility and rural women's land use rights), in Lin Tan and Bohong Liu (eds.), Zhongguo funü yanjiu shi nian (10 year review of Chinese women's studies), Beijing, Shehui kexue wenxian chubanshe, 2005, pp. 683-691.

33. H. Ray Liaw, "Women's land rights in China: Transforming existing laws into a source of property rights," Pacific Rim Law and Policy Journal, Vol. 17, No. 1, 2008, pp. 237-264.

34. Zhangbao Zhong and Jinhua Di, "Tudi liuzhuan zhong funü de diwei yu quanyi" (Women's status and rights in land circulation), in Lin Tan and Bohong Liu (eds.), Zhongguo funü yanjiu shi nian, Beijing, op.cit., pp. 424-432.

35. One fen equaled 1 percent of one yuan. The fen is no longer minted. Interview, Yuxi, May 2008.

36. Sally Sargeson, "Building for the Future Family," art. cit.; "Coverning women's capabilities in China's urban expansion," art. cit:; Sally Sargeson, "Women's Property, Women's Agency in China's 'New Enclosure Movement," art. cit; Sally Sargeson and Yu Song, "Land Expropriation and the Gender Politics of Citizenship," art. cit.

37. Xiaoyun Li et al., "Gender and Poverty in China: Qualitative Analysis," in China: Research Report on Gender Gaps and Poverty Reduction, Beijing, World Bank, 2006, pp. 147-266.

38. Jingxin Wang, "Zhongguo nongcun funü tudi quanyi" (Chinese rural women's land rights), Zhongguo nongcun jingji (China's rural economy), No. 6, 2003, pp. 25-31. 
orthodox custom of virilocal post-marital settlement - "women follow men." (39)

This narrative illuminates the ideological framing of gender in China. However, it hinges on a classic a-historical othering manoeuvre that Fabian describes as a "denial of coevalness." ${ }^{(40)}$ At its core is a discursive temporal/spatial opposition between what are depicted as the primordial traditions of a "backward," culturally inert countryside and the dynamic cultures of modern urbanism. Implicit in this opposition is the premise: modernise the village, bring it into the urban space of the twenty-first century, and Confucian patriarchy will weaken. Yet the disjuncture between city and countryside has blurred as a result of industrialisation, urbanisation, the expansion of high-speed transport and communications infrastructure, and mass rural-urban labour migration. Villagers, in many respects, already share the same territorial horizons, legal framework, cultural practices, work routines, and commercialised desires as urbanites. This begs explanation of the mechanisms perpetuating Confucian patriarchal values in a mobile, rapidly urbanising society.

A second explanatory narrative is predicated on another progressivist assumption, one that is common to both Marxist emancipatory theory and the individualistic off-shoot of liberal economics: human capital theory. Since the 1950s, Engels' dictum that women's entry into the paid workforce would improve their status has informed interventions by China's government and Women's Federation to mobilise women as workers. Moreover, the government still claims that women earn less than men primarily because of residual gender gaps in education, training, and employment. The implication is that women who acquire education and skills will prosper. A similar assumption underpins a recent World Bank study on poverty in China, which concludes that as labour market competition intensifies, income and wealth inequalities increasingly will reflect variations in human capital. ${ }^{(41)}$

This explanation is not supported by the available evidence. Despite a reduction in differentials between male and female education and training, and despite women's high rate of participation in paid employment, the gender gaps in both income and assets have increased over recent years. The rate of increase has been greater in wealthier provinces where labour markets are most developed. ${ }^{(42)}$ To the extent that asset distribution does not reflect disparities in individuals' human capital endowments, but rather gender categories, this narrative fails to explain these gaps. Aside from factual inaccuracy, another problem with this narrative is that it is deployed to encourage women to compete in education and factor markets whilst discouraging inquiry into the reasons for the disconnect between human capital, earnings, and wealth in those markets.

A residualist view of institutions is central to the third most widely purveyed narrative. Here, gender inequality is explained as the result of disjunctures between old collectivist institutions, transitional regulations intended to secure the conditions for rural household commodity production, and recent laws aimed at empowering individual property holders in factor markets. Liaw, for example, argues that the insecurity of rural women's property derives partly from shortcomings and contradictions in the RLCL, Property Law, and revised Marriage Law of 2001. ${ }^{(43)}$ Although Article 30 of the RLCL stipulated that women who marry virilocally retain rights in their natal households' contract land unless the village into which they marry allots them a plot, its prohibition against villages' adjustment of land among households negated the mechanism providing in-marrying women with farmland. ${ }^{(44)}$ Revisions to the Marriage Law changed the marital regime from full community property (in which assets acquired both before and during the marriage are jointly owned by spouses) to partial community property (only assets acquired during the marriage are jointly owned; assets acquired prior to marriage remain individual property). Thus, women marrying into households with 30-year land contracts and houses lost their rights in marital land or housing. Even if women subsequently receive land in readjustments, or newly-weds jointly re-contract land, women remain vulnerable to dispossession in the case of marital breakdown because neither the RLCL nor Property Law explicitly define land contracts as "jointly owned" property. This precludes the partitioning of contract land in the event of divorce. In addition to the gender blindness of national legislation, the implementation of village "self-government" has allowed gender-discriminatory customs to be formalised as village rules. It was her recognition of this fact that prompted the Zhejiang interviewee quoted above to remark, "Actually, the village rules are even more important to us than the laws!" Like the arguments outlined above, the implication is that legislative and policy reform will remove gender inequalities. What remains unexplained is why, in recent changes to both law and customary rules, women consistently have lost out.

Each of these narratives offers insight into factors contributing to the gender asset gap. Ultimately, however, each contains a problematic teleological assumption: when villagers modernise, or when women are employed, or when regulatory institutions are updated and made consistent, gender inequalities should disappear. So, too, should the gender asset gap. In light of the evidence reviewed above, these assumptions seem misguided. To construct a more credible explanation, we need to refer to a non-teleological relational theory that will assist us in identifying dynamics reproducing the gender asset gap in the course of urban transformation.

Charles Tilly's theory of categorical sources of durable inequality offers a useful corrective to explanations of why China's women own less. Although Tilly did not focus on China, and indeed his work has influenced comparatively little scholarship on inequality in China, ${ }^{(45)}$ his argument grew precisely from his critique of the types of a-historical, individualist accounts of inequality that are outlined above. For Tilly, binary relational categories are a central organising feature of all societies. The gist of his theory of how these categories give rise to and sustain inequalities is articulated in succinct statements in two key publications: "Durable inequality among categories arises because people who control access to value-producing resources solve pressing organizational problems by means of categorical distinctions. Inadvertently or otherwise, those people set up systems of social closure, exclusion and control. Multiple parties - not all of them powerful, some of them even victims of exploitation - then acquire stakes in those solu-

39. Virilocal marriage involves the bride's movement to the groom's place of residence. See Zhenglin Guo, "Nongcun funü de tudi quanli yu zhengce baozhang" (Rural women's land rights and protective policies), in Lin Tan (ed.), 1995-2005 nian: Zhongguo xingbie pingdeng yu funü fazhan baogao (1995-2005: report on gender equality and women's development in China), Beijing, Shehui kexue wenxian chubanshe, 2006, pp. 149-159.

40. Johan Fabian, Time and the Other: How Anthropology Makes its Object, New York, Columbia University Press, 1983.

41. World Bank, From Poor Areas to Poor People: China's Evolving Poverty Reduction Agenda, Beijing, World Bank, 2009, p. 159.

42. Philip N. Cohen and Wang Feng, "Market and Gender Pay Equity: Have Chinese Reforms Narrowed the Gap?", in Deborah S. Davis and Feng Wang (eds.), Creating Wealth and Poverty in Postsocialist China, Stanford, Stanford University Press, 2009, pp. 37-53.

43. H. Ray Liaw, "Women's land rights in China," art. cit.

44. Ping Xu, "Hunying liudong yu nongcun funü de tudi shiyong quanyi," in Lin Tan and Bohong Liu (eds.), Zhongguo funü yanjiu shi nian, Beijing, Shehui kexue wenxian chubanshe, 2005, pp. 683691.

45. One exception is Wang Feng, Boundaries and Categories: Rising Inequality in Post-Socialist China, Stanford (CA), Stanford University Press, 2008 
tions." (46) "[E]xterior categories ... such as gender... become interior to the extent that members of organizations create widely recognized names for the boundaries and actors, enact defining rituals, and represent the categories by symbolically explicit devices." (47) Inequalities between the categories are not only entrenched, but also will be magnified when "repeated transactions across the boundary (a) regularly yield net advantages to those on one side and (b) reproduce the boundary." (48) This suggests that when a dominant category owns most assets, and controls the decision-making organisations and rules distributing assets, it will reinvest part of the surplus it receives through opportunity hoarding and exploitation in reinforcing the boundaries between it and the other category. ${ }^{(49)}$

Before applying Tilly's argument to empirically examine how gender distributive inequalities are produced in urbanising China, it is worth briefly comparing his view with two other influential theoretical approaches. Sceptics have questioned how Tilly's theory differs from the institutionalist concept of "path dependence." (50) For Tilly, cultural scripts matter, but they are of second order causal importance compared to the agency that relationally categorised people exercise. Thus, whereas the high level of determinism implicit in the concept of "path dependency" makes it difficult to explain change, (51) in Tilly's schema, actors make and remake institutions. Moreover, whereas scholars of "path dependency" largely have overlooked the links between gender, institutions, and distribution, ${ }^{(52)}$ for Tilly gender is a fundamental category that structures organisations, and which those organisations routinely reproduce in their rules, roles, and transactions. Marxists, on the other hand, have questioned how the mechanisms through which Tilly's categories sustain inequality differ from class relations. As Erik Olin Wright points out, the originality of his argument is precisely that it extends a materialist analysis to patterns of categorical inequality overlooked by Marx. ${ }^{(53)}$ For scholars interested in the gender consequences of rural China's momentous urban transformation, Tilly's argument provides a useful lens through which to analyse how organisations utilise discourses, rules, and practices attached to gender categories to enable men to acquire and exploit the value that urbanisation adds to their assets. It is to this task that I now turn.

\section{Reinforcing gender categories, redistributing assets in rural China's urban transformation}

When rural collectively-owned land is expropriated by local governments and villagers' housing, agricultural, and business assets are demolished to make way for urban development, most compensation is paid to the rural collective economic organisation that represents the collective owners of the land. Typically, this is the Village Committee. Compensation predominantly is monetary, but might also include provision for villagers' relocation in urban settings, vocational training, and employment assistance, and inclusion in local pension and insurance funds. By tracing the distribution of compensation, registration, and use of new assets and organisation of work and social reproduction in urban areas, we gain insights into how local governments, households, and Village Committees instrumentalise gender to solve the distributional challenges posed by urban expansion. I follow this path in reverse, starting with the male-dominated organisations that govern villages.

After deducting a percentage of the compensation for future collective economic ventures and, often, for embezzlement by the village leaders, Village Committees then redistribute the remaining compensation among eligible households and individual villagers. The Committees seek to maximise the amount made available to each villager - and so reduce the likelihood they will suspect and protest against embezzlement - by limiting the potential number of claimants. In peri-urban sites in Zhejiang, Yunnan, Hunan, and Fujian, one common way this is achieved is by using gender and virilocal marriage customs as the basis for determining village membership and consequent eligibility for compensation. Village rules typically grant local men entitlements to a full share of compensation for expropriated assets as a patrilineal birthright. But under the same rules, local women are considered to be village members only until such time as they marry. After marriage, their membership status, and their entitlement to compensation for any expropriated assets, is determined by their husbands' status. Women married to non-local men are thereby deemed to be ineligible for a share of compensation. Some villages even anticipate the impending "out-marriage" of unwed girls in the village by apportioning them only half the compensation sum given to their brothers. It is not only local men, but also their mothers and wives long accepted as village members that have a stake in supporting the use of gender and virilocal custom as a just basis for the distribution of compensation. By excluding or giving less to women who are unwed, out-married, in de-facto relationships, and divorced, men and the women affiliated to them gain more.

Village Committees' methods of transferring monetary compensation also favour men. Although rural women disproportionately are disadvantaged by the elimination of farming livelihoods and home-based businesses, in the four provinces in which I conducted research approximately 20 percent of women farmers never received any monetary compensation for the loss of their livelihoods. ${ }^{(54)}$ This was either because they were deemed ineligible for compensation, or because their share of compensation was paid to someone else: usually, the male household head. In all, monetary compensation for all members was pooled and paid into the bank account of the household head in 65 percent of households. Payments into men's bank accounts reinforce their normative status and financial clout as household heads. As one interviewee explained, "It is natural for men to support women, but if a woman supports a man people will look down on him." (55) Moreover, some Committees pay men an extra premium, and so give them "face" as family "breadwinners." In areas around Changsha, in Hunan, Song and I found that villages' decisions to grant the maximum possible sum of monetary compensation to men aged 23 to 50 , but to women aged from only 25 to 40, effectively ensured that men received several hundred thousand yuan more from each village's pool of compensation. The welfare of their elderly parents, as well as wives, thereby became contingent on their maintenance of good relations with the household head: "If the son was

46. Charles Tilly, Durable Inequality, op. cit., pp. 7-8.

47. Ibid, p. 80

48. Charles Tilly, "Changing Forms of Inequality," art. cit., p. 34,

49. See also Arne Sorenson, "The structural basis of social inequality," American Journal of Sociology, Vol. 101, 1996, pp. 1333-65.

50. My thanks to one of the anonymous evaluators of this article for asking this question.

51. Elizabeth Clemens and James Cook, "Politics and Institutionalism: Explaining Durability and Change," Annual Review of Sociology, Vol. 25, 1999, pp. 441-66; Stephen Bell, "Do we really need a new 'constructivist institutionalism' to explain institutional change?", British Journal of Political Science, Vol. 41, 2011, pp. 883-906

52. Fiona Mackay, Meryl Kenny and Louise Chappell, "New Institutionalism through a Gender Lens: Towards a Feminist Institutionalism?", International Political Science Review, Vol. 31, No. 5, 2011, p. 579.

53. Erik Olin Wright, "Metatheoretical Foundations of Charles Tilly's Durable Inequality," Comparative Studies in Society and History, Vol. 42, No. 2, 2000, pp. 458-474.

54. Sally Sargeson, "Women's Property, Women's Agency in China's 'New Enclosure Movement," art. cit:; Sally Sargeson and Yu Song, "Land Expropriation and the Gender Politics of Citizenship," art. cit.

55. Interview, Ningbo, June 2006. 
married, the village government naturally paid him for the household. So some parents missed out. If they got along with their son they'd live with him. But if they didn't get on with their son they had to make their own living. The government refused to care for them." (56)

In situations where compensation "naturally" becomes the property of men by virtue of their gender and the rights and roles attached to it, women will rationally attempt to secure a share of compensation by similarly conforming to the roles attached to their gender in patrilineal, male-headed households. Women of all ages anchor their property entitlements in their performance as agreeable, or at least dutiful, mothers, wives, and daughters. Citing the old adage, "Men manage outside, and women manage inside," and playing up presumptions about women's risk-averse, caring nature, they argue that husbands should turn the households' compensation over to them for saving, investment in children's education, and the care of aging parents. Women who fail to conform to female gendered roles or who contest village rules are chastised for their cultural ignorance and questionable morality.

The small percentage of women courageous enough to appeal to governments to protect their legal entitlement to a share of compensation irrespective of their marital status risk not only social ostracism from their community, but also the rejection of their claims by local government authorities, who find it politically expedient to placate village men angered by the paltry compensation sums that the governments have paid for land taking. In other words, governments are complicit in the reproduction of the gender asset gap. Officials justify their refusal to overturn gender discriminatory village rules by arguing, first, that the Organic Law entitles villages to apply customary rules to exclude opportunistic claimants so that "genuine" villagers (i.e., the members of patrilineal households) receive adequate compensation. Second, by criticising the "self-interested" motives of women protesters, they reinforce normative expectations that good wives behave altruistically with regard to assets. As one community official complained:

We've had two go to Beijing, petitioning. One, from Zhejiang, she'd already been married into several places. Then she married a man here, but she didn't care for him. All she was interested in was getting her hands on some property, village benefits. But the village, it said only after three full years would she get anything. So she went to Beijing and petitioned, and the government gave her more than one thousand - even we officials don't get a thousand - a dibao ${ }^{(57)}$ payment of one thousand three hundred! But oh no, that wasn't enough. She still went on petitioning, because although the village gave her somewhere to live, she even wanted her own house! (58)

Major new assets such as urban apartments, and investments in small businesses, properties, shares, and interest-bearing deposits were predominantly registered in men's names. For example, among 343 households relocated to new urban residences in Zhejiang, Yunnan, Hunan, and Fujian, I found that only 71 registered women's names on the house titles. In contrast, the 2010 Survey on the Status of Chinese Women reported that in its sample (comprising 52.5 percent urban and 47.6 percent rural people), 37.9 percent of women "owned" housing. Unfortunately, the published report does not explain whether all these women had registered title to housing. But amongst married couples, it notes that 51.7 percent of men and 13.2 percent of women held sole title to their houses. ${ }^{(59)}$ This suggests two things: first, there is significant gender inequality in the ownership of the single largest component of urban families' wealth; second, while married men usually own homes as individuals, most women achieve ownership as wives, via community property. As explained above, many would have difficulty defending their property in the event of divorce.

The gender-unequal distribution of compensation and new housing gives men indisputable advantages in capitalising on new opportunities in the urban economy. Asked which family members decide how to use compensation funds, one interviewee scoffed, "Men very rarely allow a woman to decide something important. You only need one hand to count the number of households in which a woman is the decision-maker!" (60) Without either monetary compensation or title to housing, most women lack the collateral to secure loans from formal financial organisations in the city. A small minority uses their home-owning husbands as proxy borrowers and licensees to establish small businesses. For example, in the highly entrepreneurial district of Xiuzhou, Ningbo, in 2004 only 80 women but several hundred of the men among the 20,000 landless villagers there had established businesses. Even among long-term urban residents, Zhang and Pan found that men had greater access to start-up capital and business assets. ${ }^{(61)}$ Over time, wives' capital dependence and domestic work burden tends to undermine their control over the businesses, relative to their husbands. The expenditure of compensation, income, and profits on masculinist, social capital-enhancing rituals such as banqueting further entrenches the gender gap in family businesses. Thus, the gender categories utilised by Village Committees and governments to legitimate unequal wealth distributions among the men and women caught up in rural China's urban transformation become implicated in the gendering of urban entrepreneurship.

As Tilly's theory would predict, urban governments have constructed gender differentiated employment and pension systems that facilitate the exploitation of women's labour. Former women farmers are enlisted to work in urban enterprises, neighbourhood management, and the voluntary care sector. Ideologically, this is in keeping with the Chinese government's argument that increasing women's employment will reduce gender inequality. Yet the strategies implemented by local authorities actually exacerbate gender income inequality, whilst maintaining China's price competitiveness in global commodity production chains. Women are directed into labour-intensive electronics, toys, clothing, and footwear manufacture, domestic service and sanitation, and home-based assembly work - sectors notorious not only for low pay, but also for poor protection of workers' rights and safety. Those who choose unemployment to unwaged work are criticised, in terms that combine old notions of socialist-productivist morality and a liberal-individualist interpretation of feminism, as "not contributing to society," of having "poor quality," and "free-loading." Men are trained and encouraged to work as enterprise technicians, in the more highly remunerated sectors of transport and construction, or to establish small businesses. While men are expected to continue working until they reach 60 , women typically become eligible to draw pensions five to ten years earlier than men. Men thus accumulate larger pension funds than women. This is justified, accord-

56. Interview, Changsha, December 2008

57. Dibao refers to the minimum livelihood guarantee. The amount referred to in the quote is the total annual sum awarded to the recipient, which was delivered in monthly installments of 108 yuan.

58. Interview, Yuxi, December 2008.

59. Quanguo Fulian (All-China Women Federation), "Di san ci Zhongguo funü shehui diwei diaocha zhuyao shuju baogao," art. cit.

60. Interview, Jinhua, March 2006.

61. Qian Forrest Zhang and Zi Pan, "Women's Entry into Self-Employment in Urban China:The Role of Family in Creating Gendered Mobility Patterns," World Development, Vol. 40, No. 6, 2012, pp. 1201-1212. 
ing to official interviewees, because it "frees up" - and obligates - middleaged women to perform voluntary community service and care work. But it also encourages households to try to protect men's earnings by buying them commercial medical, unemployment, and old age insurance.

What are the women to do? Asked how women occupy themselves during their many years of retirement, an official in Quzhou, Zhejiang, voiced the common expectation that "older women can make a contribution as volunteers, cleaning the neighbourhood." (62) Women's participation in neighbourhood beautification and home renovation projects maintain the value of real estate owned by local governments, business people, and household heads. Others insisted that women like to retire early so they can care for their parents-in-law and grandchildren. Making community service and care work the primary function of women reinforces the normative conflation of wife and inside/domesticity which is implicit in the Chinese term "neiren." But as Song and I have written elsewhere, some officials represent governments' land-taking as a process positively reinforcing village women's assimilation into "modern" urban gender roles:

As the community becomes more urbanised, they start dressing up like us urbanites. This really brings them a lot of benefits. So when we have meetings with them, we remind them, "You should remember what advantages the state has brought you! Say you still lived in the village, were still a rural woman, how could you be choosing skirts, looking at pictures, making up your faces so beautifully, and have money in your hands the way you do now? ${ }^{(63)}$

In addressing the distributional problems that arise in the context of urban expansion, male-dominated Village Committees, patrilineally defined households, and governments instrumentalise gender as a fundamental category to implement and justify gender-unequal distribution and exploitation. Monetary compensation disproportionately is paid to men, and the more valuable, institutionally secure real estate and businesses acquired by former villagers in urban areas are predominantly registered in men's names. Returns from men's assets are reinvested in gender-defining roles, rituals, and symbols. At the same time, governments' employment and welfare interventions help to make former rural women's labour available at low cost, if not for free, to urban businesses and male-headed households. Adding to the impact of the gender asset gap, women are encouraged to interiorise market-rational values from a gender relational standpoint, in ways that constrain their subjectivity and agency with respect to assets.

\section{Conclusions}

The question of why women own less in urbanising China is not satisfactorily answered by the most widely circulated arguments. Contrary to the teleological assumptions apparent in those arguments, urbanisation actually perpetuates the gender asset gap. Drawing on Charles Tilly's theory of how categories are used to reinforce and reproduce inequalities, this article offered a different account of the asset gap. Empirically, it illustrated how gender categories are instrumentalised in Village Committees' definitions of village membership and compensation eligibility and methods of compensation payment, households' registration of new housing, business and insurance assets, and governments' employment strategies and welfare programs. The asset gap, in turn, sustains gender relations of opportunity hoarding and exploitation. While former village men accumulate value-pro- ducing property in the new urban space, most women are incorporated into urban economies and societies as propertyless, feminised workers in, unpaid domestic caretakers of, and dependents on assets owned largely by men. Gender is a key axis of asset distribution and role allocation in rural China's urban transformation.

What are the implications of this argument for gender relations, as China urbanises?

The material implications seem inevitable: Wealth inequalities between men and women will increase rather than decline in the medium term. In this event, gender inequalities in income are unlikely to narrow, regardless of improvements in women's human capital endowment and employment participation.

The repercussions of this argument for changes in women's subjectivity and agency are, in some ways, more troubling. The question of who owns assets goes to the heart of our understandings of who are the active agents of modernity. For liberal economists, the active agent of the market economy is presumed to be a rational, autonomous wealth maximiser. This presumption has informed calls for Chinese land contract rights to be transformed into individual ownership in order to increase farmers' incentives to invest - despite the fact that in most households, land contractors and farmers are of different sexes and are motivated by different incentive structures. Similarly, in the classic imaginary of Madisonian democracy, it is partly in order to protect its property that the (male) majority is motivated to resist oppression and arbitrary extraction. Of course, many dispute the methodological individualist ontology underpinning liberal presumptions. But the logical extension of this thinking, as it is being applied in institutional and policy reforms, is that men and women are being manoeuvred into different modes of behaviour, with propertied men acting as economic and political principals, and women serving as their dependent, domesticated agents. Asset distribution is circumscribing the subject positions and dimensions of agency available to women affected by urban growth.

Finally, this argument also has relevance for the Chinese government's credibility with regard to its long-standing commitment to support women's equality. Since the beginning of the twenty-first century, China's leaders have been promoting what they anticipate to be a virtuous circle of urbanisation, capital investment, and economic structural transformation, and improvements to the populations' wealth and well-being. But unless action is taken to define, register, and enforce women's ownership of assets in each turn of this policy circle, the wealth generated will be unequally distributed between gender categories. In that event, the Chinese government will have failed to fulfil one of its core social justice commitments.

I Sally Sargeson, a Fellow in the College of Asia and the Pacific at the Australian National University, is currently researching land development, violence, and gendered village governance. Her most recent book, co-edited with Tamara Jacka, is Women, Gender and Rural Development in China (Northampton [MA]/Cheltenham, Edward Elgar, 2011).

Department of Political and Social Change, Hedley Bull Building,College of Asia and the Pacific, The Australian National University, Canberra, ACT, 0200 Australia (sally.sargeson@anu.edu.au).

62. Interview, Quzhou, April 2006.

63. Cited in Sally Sargeson and Yu Song, "Land expropriation and the gender politics of citizenship in the urban frontier," art. cit., p. 22 